\title{
Work Motivation and Job Satisfaction of Employees of a Retail Company in Negros Island
}

\author{
Nikki V. Guinto ${ }^{1}$ and Celo I. Magallanes ${ }^{2}$ \\ ${ }^{1} \mathrm{KJ}$ Fairmart Inc., Bacolod City, Philippines \\ 2University of Negros Occidental-Recoletos, Bacolod City, Philippines
}

\author{
Article history \\ Submitted: 23 October 2020 \\ Revised: 12 November 2020 \\ Accepted: 13 November 2020 \\ Keywords \\ Guidance and Counseling \\ Work Motivation \\ Job Satisfaction \\ Employees \\ Retail Company \\ Descriptive-Correlational \\ Negros Occidental
}

Introduction. Factors such as work motivation and job satisfaction are essential to each other must be present in a company for employee performance. Work motivation and job satisfaction will increase employee commitment. These will enable the organization to be more productive and deliver excellence when employees are more interested in their work. The result is higher in quality, and employees are more fulfilled. Hence, the paper explores the difference in the extent of employees' work motivation and job satisfaction grouped according to demographics such as age, sex, educational attainment, years of service, employment status, and position. Likewise, it determined the relationship between employees' work motivation and job satisfaction for the Year 2019-2020.

Methods. A descriptive-comparative correlational research design was used to assess, compare, and correlate work motivation and job satisfaction when employees are grouped according to demographics. Using stratified random sampling, 225 employees participated in the study. The data were collected using two (2) standardized instruments, namely, the Multidimensional Work Motivation Scale (MWMS) by Gagne et al. (2015) and Minnesota Job Satisfaction Questionnaire by Weiss et al. (1967). Mean, Standard Deviation, and Pearson Product Moment correlation were used to analyze the data.

Results. The findings revealed that employees are strongly motivated in all areas of work motivation. Likewise, retail employees are satisfied in all dimensions of job satisfaction. No significant difference was revealed in the extent of work motivation when employees are grouped according to age, sex, years of service, educational attainment, employment status, and position. Likewise, there was no significant difference in the level of job satisfaction when employees are grouped according to the aforementioned variables. However, there was a significant difference in job satisfaction level when employees are grouped according to educational attainment. High school graduates were more satisfied than their college counterparts. Finally, a significant relationship exists between work motivation and job satisfaction of employees.

Conclusion. The employees working in a retail company are strongly motivated to work and are satisfied with their jobs. Demographic variables such as age, sex, years of service, employment status, educational attainment, and position did not make any significant difference in the employees' work motivation. The same is also true with job satisfaction level, except educational attainment, which implies that college graduates want more intrinsic and extrinsic sources of job satisfaction. It can also be implied that the strongly motivated workers are satisfied with their jobs, thus have more chances to be engaged and committed to the company's vision and mission. Since the employees are motivated and satisfied, the company must ensure that the working environment sustains or enhances the employees' work motivation and satisfaction for the organization's betterment.

Practical Value of the Paper. The study contributes to the existing literature on work motivation and job satisfaction of retail employees. afford new knowledge to employers and the human resource department regarding their employers' work motivation and job satisfaction. They can value them as partners in the company's growth and productivity. Also, the findings served as a basis for designing a proposed motivational plan for employees. 


\section{References}

Adeleye, E., Lawal Y. \& Olatunde, O. (2015). Investigating the Relationship between Employee Motivation and Job Satisfaction, Abuja Journal of Business and Management Vol.1, Issue 1 [1-10], March-2015.

Angeles, V., Saludo, A. M, Virtus, L.M., \& Win, M. (2015). Job Satisfaction and Performance Level Of Employees of Ajinomoto Philippines Corporation Lucena Branch Angeles, LPU-Laguna Business and Accountancy Journal, Vol. 1 No.2 September 2015.

Choudhary, M. (2016) Role of Employee Motivation \& Customer Experience, International Journal of Core Engineering \& Management, Volume 2, Issue 12, March 2016, ISSN: 23489510.

Huang, Q. \& Gamble, J. (2015). Social expectations, gender, and job satisfaction: Front-line employees in China's retail sector. Human Resource Management Journal. 25. 10.1111/1748-8583.12066.

Kadapure, P. \& Dasar, S. (2018). Determinants of Employee Job Satisfaction in Retail Sector in India, International Journal of Management Studies ISSN (Print) 2249-0302 ISSN: 2231-2528 Vol.-V, Issue -2(3), April 2018 [105].

Naga, R., Sree, B., \& Satyavathi, R. (2017). Employee Job Satisfaction, International Journal of Engineering and Management Research Page Number: 85-94, ISSN: 2394-6962 85.

Prasad, R. (2018). Contemporary Motivation Tools Adopted by Strategic HR Managers, International Journal of Trend in Scientific Research and Development International Open Access, Journal ISSN No2456-6470 Volume 2 Issue 4.

Samaiya, S. (2015). Comparison of Employee Satisfaction along with Age and Gender: Study of Public and Private Sector Journal of Business and Management (IOSR-JBM) e-ISSN: 2278-487X, p-ISSN: 2319-7668. Volume 17, Issue 8.Ver. IV (Aug. 2015), PP 44-52 www.iosrjournals.org DOI: 10.9790/487X-17844452 www.iosrjournals.org.

Sattar, A., Khan, S. \& Nawaz, A. (2010). Theories of job satisfaction: Global applications \& Limitations. Gomal University Journal of Research. 26. 45-62. Retrieved from https://www.researchgate.net/publication/286932201_ Theories_of_job_satisfaction_Global_applications_Limitations

Thiagaraj, D. \& Thangaswamy, A. (2017). Theoretical Concept of Job Satisfaction - A Study. International Journal of Research - Granthaalayah, 5(6), 464-470. https://doi.org/10.5281/zenodo.822315. Retrieved from: https:// vdocuments.mx/reader/full/theoretical-concept-of-job-satisfaction-thiagaraj-et-al-vol5-iss6

\section{Correspondence:}

Nikki V. Guinto [nikkiguinto113@gmail.com]

https://orcid.org/0000-0002-2876-8674 